\title{
Affinity-based enrichment strategies to assay methyl-CpG binding activity and DNA methylation in early Xenopus embryos
}

\author{
Ozren Bogdanović and Gert Jan C Veenstra*
}

\begin{abstract}
Background: DNA methylation is a widespread epigenetic modification in vertebrate genomes. Genomic sites of DNA methylation can be bound by methyl-CpG-binding domain proteins (MBDs) and specific zinc finger proteins, which can recruit co-repressor complexes to silence transcription on targeted loci. The binding to methylated DNA may be regulated by post-translational MBD modifications.

Findings: A methylated DNA affinity precipitation method was implemented to assay binding of proteins to methylated DNA. Endogenous MeCP2 and MBD3 were precipitated from Xenopus oocyte extracts and conditions for methylation-specific binding were optimized. For a reverse experiment, DNA methylation in early Xenopus embryos was assessed by MBD affinity capture.

Conclusions: A methylated DNA affinity resin can be applied to probe for MBD activity in extracts. This assay has a broad application potential as it can be coupled to downstream procedures such as western blotting, fluorimetric HDAC assays and quantitative mass spectrometry. Methylated DNA affinity capture by methyl-CpG binding proteins produces fractions highly enriched for methylated DNA, suitable for coupling to next generation sequencing technologies. The two enrichment strategies allow probing of methyl- $\mathrm{CpG}$ protein interactions in early vertebrate oocytes and embryos.
\end{abstract}

\section{Background}

DNA methylation is an epigenetic modification mostly associated with transcriptional repression in vertebrate genomes. In vertebrates, methylation events occur predominantly within the context of $\mathrm{CpG}$ dinucleotides, which in mammals by and large are methylated [1,2]. The repressive signal inferred by DNA methylation is further interpreted by methyl-CpG binding domain (MBD) proteins that bind sites of DNA methylation and can recruit complexes with histone deacetylase (HDAC) activity to silence transcription [3-6]. The MBD was initially described as the minimal part of the MeCP2 protein required for methylated DNA binding [7]. Four remaining family members (MBD1, MBD2, MBD3 and MBD4) have been discovered on the basis of homology searches with the MeCP2 MBD amino acid sequence

\footnotetext{
* Correspondence: g.veenstra@ncmls.ru.nl Department of Molecular Biology, Nijmegen Centre for Molecular Life Sciences, Radboud University Nijmegen, Faculty of Science, (Geert Grooteplein 28), Nijmegen, (6525 GA), The Netherlands
}

[8]. In addition, several structurally unrelated methylCpG binding proteins have been identified $[9,10]$. Mutation or knockdown of DNA methyltransferases and MBD genes result in severe developmental phenotypes [11-14]. Mutations in the MBD family founder, MeCP2, are the cause of Rett Syndrome (RTT), a grave neurodevelopmental disorder which due to its $\mathrm{X}$ chromosome linkage almost exclusively affects females $[15,16]$. In post-mitotic neurons, the brain-derived neurotrophic factor (BDNF) promoter III is controlled by phosphorylation-dependent MeCP2 binding [17,18]. Membrane depolarization results in MeCP2 phosphorylation, carried out by the CamKI kinase, which diminishes its binding affinity for methylated DNA $[19,20]$. A number of methods to study DNA-protein interactions have been developed over the years. For example, chromatin immunoprecipitation (ChIP) coupled to microarray hybridization or Next-Generation Sequencing technologies has facilitated the generation of genomic maps of transcription factor binding sites [21,22]. Other widely

\section{() Biomed Central}


used methods to study DNA-protein interactions involve DNA footprinting, EMSA (Electrophoretic Mobility Shift Assay), southwestern blotting (SW), DNA affinity chromatography and DNA-protein crosslinking in vitro (DPC) $[23,24]$ DNA affinity precipitation is an efficient method for the analysis and purification of proteins displaying sequence specificity for DNA $[25,26]$. Such assays can be used to study binding affinity and recruitment specificity of either recombinant or cellular proteins $[27,28]$. Recently, important progress has been made in understanding the interactions of modified histone tails with transcriptional regulators [29-31]. These studies have combined peptide affinity pull-downs and quantitative mass spectrometry enabled by SILAC (Stable Isotope Labeling by Amino Acids in Cell Culture) [32]. It will be of great importance to define proteins recruited to methylated DNA during early development. For over a century amphibians from the genus Xenopus have been the organisms of choice to study developmental processes. The main reason for this is external embryonic development as well as the relatively large size of the embryos themselves which allows easy experimental manipulation. A number of studies involving DNA methylation and methyl-CpG binding proteins established Xenopus laevis as an important model for epigenetics studies [9,33-35]. Sequencing of the Xenopus tropicalis genome rendered this organism suitable for (epi)genomics studies of the early vertebrate development [36-38]. Here we describe an efficient method for methylated DNA affinity precipitation of MBDs from Xenopus oocytes. Using in vitro methylated DNA oligonucleotides bound to magnetic beads and conditions that promote methylation-specific binding, MeCP2 and MBD3 were pulled down. These methylated DNA affinity precipitation assays have a broad application potential as they can be combined with a number of biochemical techniques and used in different model systems. Furthermore, to test the ability of MeCP2 to affinity-precipitate methylated DNA from early Xenopus embryos, the immobilized MBD domain of MeCP2 can be used to enrich for methylated genomic DNA [39-41]. The fractions enriched for methylated DNA, due to their high recovery rate, are suitable for coupling to next generation sequencing technologies.

\section{Methods}

\section{Oocyte extract preparation}

Xenopus laevis oocytes were collected in an eppendorf tube and homogenized in ice cold lysis buffer $(20 \mathrm{mM}$ Tris ( $\mathrm{pH}=8,0), 70 \mathrm{mM} \mathrm{KCl}, 1 \mathrm{mM}$ EDTA, 10\% glycerol, 5 mM DTT, 0,125\% NP40, Roche Complete protease inhibitors). The extract was centrifuged for 5 minutes at $4^{\circ} \mathrm{C}$ at maximum speed. The supernatant was collected and quick-frozen in liquid nitrogen. The final oocyte concentration in the extract was 0.5 oocyte equivalents per $\mu \mathrm{L}$ assuming that one oocyte corresponds to $1 \mu \mathrm{L}$.

\section{MeCP2-MBD in vitro transcription and translation}

The pT7TS-5'MBD construct, encoding the first 176 amino acids of Xenopus laevis MeCP2, was obtained by PCR amplification (primers 5'-gtatccgtcgacaattcggcacgagagaaaATG and 5'-acaagaggatcctcaGGCTTTCGGT TGCTTCTGTTCC), digestion of the PCR product with SalI and BamH1, blunting and ligation in the EcoRV site of pT7TS. In vitro transcription of the pT7TS-5'MBD was performed using the mMESSAGE mMACHINE T7 kit (Ambion). The in vitro translation was achieved using $1 \mu \mathrm{g}$ of RNA in a total volume of $50 \mu \mathrm{L}$ (Flexi Rabbit, Promega). The binding assay was performed in $150 \mu \mathrm{L}$ ABCD buffer $20 \mathrm{mM}$ Tris $(\mathrm{pH}=8,0), 1 \mathrm{mM}$ EDTA, $5 \mathrm{mM}$ DTT, $5 \mathrm{mM} \mathrm{MgCl}_{2}, 100 \mathrm{mM} \mathrm{KCl}$, $0,125 \%$ NP40, protease inhibitors) with $6 \mu \mathrm{L}$ of the in vitro translation reaction, using the protocol described below.

\section{DNA affinity precipitation}

The DNA probe was obtained by annealing of $50 \mu \mathrm{g}$ of two complementary oligonucleotides (5'-GATCCCGGAGTTAA and 5'-GATCTTAACTCCGG), modified from Klose et al. [42]. The annealed probe was phosphorylated with T4 polynucleotide kinase (New England Biolabs) for $2 \mathrm{~h}$ at $37^{\circ} \mathrm{C}$, purified by phenol-chlorophorm and precipitated with ethanol. The concatamerization reaction was performed at $\mathrm{RT}$ for $4 \mathrm{~h}$ with T4 ligase (Promega) in the presence of $10 \mathrm{mM}$ ATP to replenish the ATP from the ligase buffer. The ligation process was monitored using 1\% agarose gel electrophoresis. The reaction was ethanol precipitated for one hour at $-20^{\circ} \mathrm{C}$. After DNA precipitation, two biotinylated nucleotides, biotin-16-dUTP and biotin-14-dATP were used to fill in the overhangs in a polymerization reaction using the Klenow fragment (New England Biolabs). All the nucleotides in the reaction were present at a concentration of $0.1 \mathrm{mM}$. The reaction was allowed to proceed for 45 minutes at room temperature. The biotinylated DNA was then purified using a gel extraction kit (Qiagen) and the samples were recovered in 30 $\mu \mathrm{l}$ elution buffer. The biotinylated oligos $(\sim 50 \mu \mathrm{g})$ were methylated with SssI methyltransferase in a $500 \mu \mathrm{l}$ reaction for $2 \mathrm{~h}$ at $37^{\circ} \mathrm{C}$. Phenol-chlorophorm extraction was used to clean the methylated DNA which was then precipitated by ethanol. The methylated probe was then coupled to streptavidin beads (DYNA beads M-280). For each $3 \mu \mathrm{g}$ of DNA, $30 \mu \mathrm{l}$ of the streptavidin beads was used. The beads were washed $3 \mathrm{X}$ with the WB (1 M $\mathrm{NaCl}, 20 \mathrm{mM}$ Tris pH 8.0, 1 mM EDTA) buffer. After washing, $3 \mu \mathrm{g}$ of the methylated probe $(10 \mu \mathrm{l})$ was 
mixed with $40 \mu \mathrm{l}$ of WB buffer. Out of the $50 \mu \mathrm{l}$ of the WB buffer, $10 \mu \mathrm{l}$ were separated for subsequent gel analysis while the remaining $40 \mu \mathrm{L}$ was added to streptavidin beads. The mixture was incubated on a thermomixer set at $30^{\circ} \mathrm{C}$ for 30 minutes with shaking. Oocyte extracts $(100 \mu \mathrm{L})$ were coupled to the immobilized probe in affinity precipitation (AP) buffer $(20 \mathrm{mM}$ Tris pH 8.0, $1 \mathrm{mM}$ EDTA, $5 \mathrm{mM}$ DTT, $5 \mathrm{mM} \mathrm{MgCl}_{2}$, $100 \mathrm{mM} \mathrm{KCl}, 0.125 \% \mathrm{NP} 40$, protease inhibitors) in a $1: 1$ ratio and left rotating over night at $4^{\circ} \mathrm{C}$. After incubation the mixtures were washed with washing buffer $(20 \mathrm{mM}$ Tris $(\mathrm{pH}=8,0), 1 \mathrm{mM}$ EDTA, $5 \mathrm{mM}$ DTT, $5 \mathrm{mM}$ $\mathrm{MgCl}_{2}, 100-200 \mathrm{mM} \mathrm{KCl}, 0,125 \%$ NP40, protease inhibitors) for three times and the bound fraction was eluted with $50 \mu \mathrm{L} 1 \mathrm{X}$ Laemmli sample buffer and analyzed by western blotting.

\section{Western blotting}

The eluate $(25 \mu \mathrm{l})$ was resolved on $10 \%$ polyacrylamide gels and subjected to western blotting. The $\alpha-\mathrm{MeCP} 2$ antibody (V17-1) was raised against the C-terminal peptide MeCP2 peptide of Xenopus laevis (PRPTRE EPVDTRTT). The final serum was affinity purified and used in a 1:1000 dilution. The ISWI, Mi-2 and MBD3 antibodies have been described before $[5,43,44]$. The western blotting protocol was performed as described before [45].

\section{Genomic DNA isolation and sonication}

Xenopus tropicalis embryos $(\mathrm{n}=50)$ were homogenized in $625 \mu \mathrm{L}(12.5 \mu \mathrm{l} /$ embryo) of homogenization buffer (20 mM Tris pH 8.0, $100 \mathrm{mM} \mathrm{NaCl}, 15 \mathrm{mM}$ EDTA, 1\% SDS, $0.5 \mathrm{mg} / \mathrm{ml}$ proteinase $\mathrm{K})$. The homogenate was then incubated for $3 \mathrm{~h}$ at $55^{\circ} \mathrm{C}$. The tubes were gently inverted after every hour of incubation. Two Phenol/ Chlorophorm/Isoamylalcohol (25:24:1, PCI) extractions were performed using the same amount $(625 \mu \mathrm{L})$ of PCI and inverting the tubes gently. The samples were spun for 5 minutes at $13000 \mathrm{rpm}$ in a table-top centrifuge following every PCI extraction. The DNA was precipitated by adding $1 / 5$ volume of $4 \mathrm{M} \mathrm{NH}_{4} \mathrm{Ac}$ and 3 volumes of cold $96 \%$ ethanol and left on ice for $1 \mathrm{~h}$. The DNA precipitate was then centrifuged for 20 minutes at $4^{\circ} \mathrm{C}$ and $13,000 \mathrm{rpm}$ in a table-top centrifuge. The pellet was washed with $500 \mu \mathrm{L}$ of $70 \%$ ethanol and centrifuged for 5 minutes, $13,000 \mathrm{rpm}$ at RT. The pellet was then resuspended in $200 \mu \mathrm{L}$ of TE buffer with $1 \mu \mathrm{l}$ of RNAse A $(20 \mu \mathrm{g} / \mu \mathrm{l})$ and left at $\mathrm{RT}$ for 30 minutes. The reaction was precipitated with 0.1 volumes of $4 \mathrm{M} \mathrm{NH}_{4} \mathrm{Ac}$ and 1 volume of isopropanol on ice for $1 \mathrm{~h}$. The precipitate was centrifuged for 20 minutes at $4^{\circ} \mathrm{C}$ at maximum speed in a table-top centrifuge and washed with $70 \%$ ethanol. The pellet was resuspended in $100 \mu \mathrm{l}$ of DNAse/RNAse free water. Two samples consisting of 50 embryo equivalents were pulled together to obtain a 200 $\mu \mathrm{l}$ sample with a concentration of $\sim 0.1 \mu \mathrm{g} / \mu \mathrm{L}$. The sample was sonicated for 15 minutes (13 seconds on, 16 seconds off, maximum output) in a Bioruptor (Diagenode) device.

\section{Methylated DNA affinity capture (MethylCap)}

Genomic DNA was sheared by sonication to $\sim 500 \mathrm{bp}$ fragments. Methylated DNA was affinity purified using the H6-GST-MBD fusion protein (Diagenode) following the manufacturers' protocol with one modification. The DNA was eluted in several steps with increasing $\mathrm{NaCl}$ concentrations $(150 \mu \mathrm{l}): 2 \times 200 \mathrm{mM}, 1 \times 300 \mathrm{mM}, 1 \times$ $500 \mathrm{mM}, 1 \times 600 \mathrm{mM}$ and $1 \times 700 \mathrm{mM}$. The recovery of methylated DNA from six genomic targets was calculated by quantitative PCR, whereas the concentration of DNA in each eluate was obtained by Picogreen measurement.

\section{Results}

\section{Immobilized DNA preparation}

To study the binding affinities of MBDs in Xenopus, small-scale DNA affinity precipitation was applied using the sequence GATC-CCGG-AGTTAA which features a single CpG dinucleotide [42]. A probe containing 11 CpG dinucleotides (6(GAC)-CCGG-6(GAC)) yielded similar results but proved more difficult to concatamerize, probably due to high CpG density of the fragment. The double-stranded oligonucleotide was methylated, concatamerized, immobilized and incubated with oocyte extracts (Figure 1A). After performing the washing steps, the proteins that bind methylated DNA were eluted. Performing the same experiment in parallel with an unmethylated oligonucleotide is a necessary control ensuring the binding occurs due to template DNA methylation and not sequence specificity alone. Following annealing and phosphorylation, the probes were concatamerized. Concatamerization is an essential step as DNA may be degraded by the exonucleases present in oocyte extracts. The concatamers ranged in size from $100 \mathrm{bp}$ $1000 \mathrm{bp}$ with the majority falling between 100 - $300 \mathrm{bp}$ (Figure 1B). To improve the concatamerization, a second round of phosphorylation and ligation may be performed. Concatamerized probes were then labeled with two biotinylated nucleotides (biotin-16-dUTP and biotin-14$\mathrm{dATP}$ ) to ensure the maximum binding efficiency in a Klenow fill-in reaction. Following biotinylation, the probes were in vitro methylated by the SssI enzyme. The extent of the methylation reaction was examined by MspI and HpaII digestion (Figure 1C). Such a digestion reaction should be performed to ensure that the probe is efficiently methylated and the concatamerization worked properly. High molar concentrations of oligos during the ligation reaction might induce concatamerization 
A

concatamerized probe

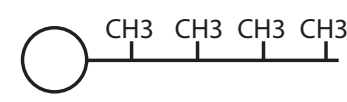

or

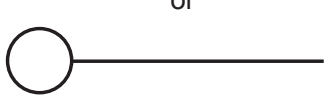

B

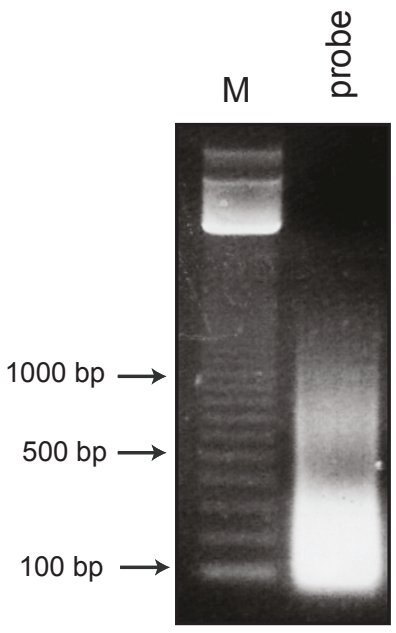

oocyte extract

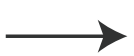

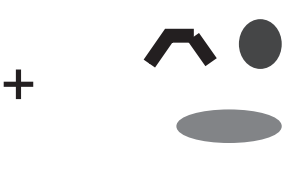

C methylation-specific binding

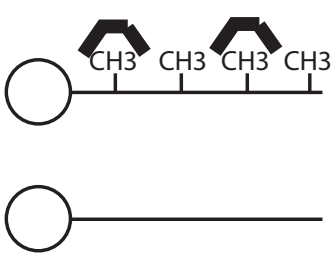

D

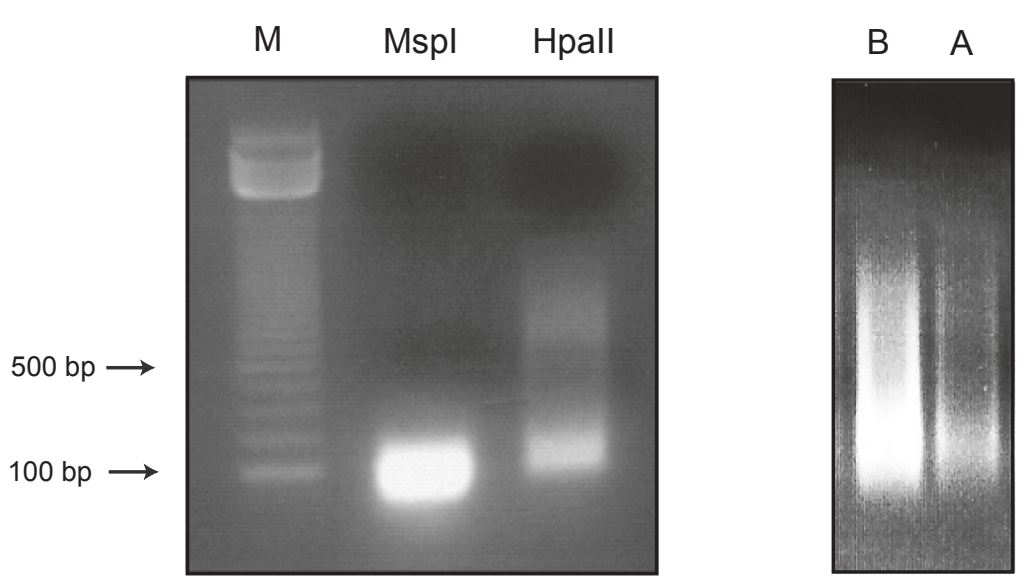

Figure 1 Methylated DNA affinity precipitation. (A) A methylated, concatamerized oligo is incubated with oocyte extract to probe for proteins with methyl-CpG binding activity. After performing the necessary washing steps, the eluate contains proteins specifically binding methylated DNA. (B) The concatamerization of the oligo is monitored by agarose gel electrophoresis. The majority of concatamerized DNA consists of fragments ranging in size from $100-300$ bp. (C) The extent of oligo methylation is measured by restriction digestion. Mspl enzyme cuts both methylated and unmethylated DNA whereas its isoschizomer Hpall cuts only unmethylated DNA. (D) The binding of the biotinylated oligo to streptavidin beads is measured by agarose electrophoresis. An aliquot of the probe before incubation with streptavidin beads (before B) is compared to a probe aliquot after 30 minutes of incubation time (after - A).

artifacts which then would not get efficiently cut by the MspI enzyme. Following the in vitro methylation reaction the probe was coupled to streptavidin beads. After incubation, $10 \mu \mathrm{l}$ of the binding reaction was compared to 10 $\mu \mathrm{l}$ of the input by $1 \%$ agarose gel electrophoresis (Figure 1D). Immobilized DNA templates coupled to streptavidin beads can be kept at $4^{\circ} \mathrm{C}$ in the same buffer used in the washing and binding steps.

\section{Binding of the in vitro translated MBD domain to immobilized templates}

To test whether the templates have assembled properly and whether the system is functional, radiolabelled $\left({ }^{35} \mathrm{~S}\right)$ MeCP2-MBD (containing amino acids 1-176 of MeCP2) and TBP2 (negative control) [46] were generated by in vitro translation using the rabbit reticulocyte lysate system. The binding occurred in the affinity precipitation buffer at $4^{\circ} \mathrm{C}$. The reaction was assembled and left overnight on a rotating platform. The following day, $10 \%$ of the input and $50 \%$ of the eluate of the binding reaction were loaded on a $10 \%$ polyacrylamide gel (Figure 2A). After exposure the visible bands were quantified using the Image-quant software (Figure 2B). A high specificity for DNA methylation-specific binding was observed; $40 \%$ of the MBD domain was recovered from the methylated probes while the recovery from the nonmethylated control was below $3 \%$. TBP2 displays very low affinity $(<1 \%$ recovery) for the methylated template whereas the binding to the unmethylated template was in the order of $\sim 4 \%$. 


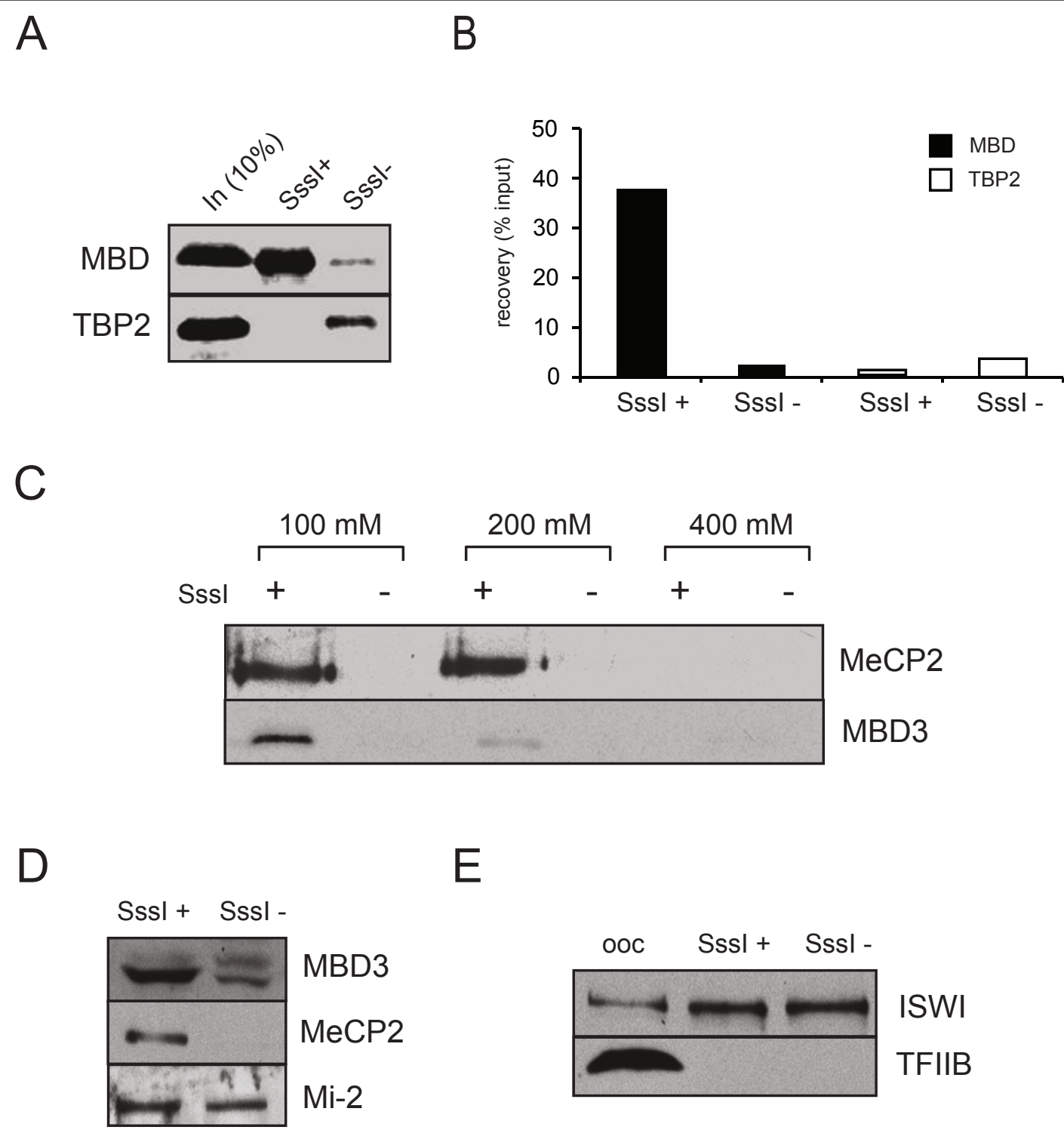

Figure 2 DNA affinity precipitation of recombinant and endogenous oocyte extracts proteins. (A) In vitro translated, $\mathrm{S}^{35}$ labeled MBD domain of MeCP2 specifically binds the methylated immobilized probe (Sssl+). Conversely, the negative control (TBP2) displays only residual affinity for non-methylated DNA (Sssl-). (B) Quantification of DNA methylation-specific binding using the Image-quant software. 35\% of the recombinant $\mathrm{MBD}$ domain is recovered after washing and elution from methylated DNA oligos. (C) Western blotting of eluates obtained after $100 \mathrm{mM}, 200 \mathrm{mM}$ and $400 \mathrm{mM} \mathrm{KCl}$ washes. MeCP2 tolerates $100 \mathrm{mM}$ and $200 \mathrm{mM} \mathrm{KCl}$ concentration in the washing buffer whereas most of the MBD3 is eluted with $200 \mathrm{mM}$ salt. (D) DNA affinity precipitation of MBD3, MeCP2 and Mi-2 from oocyte extracts. MeCP2 displays strong preference for methylated DNA, whereas Mi-2 and MBD3 bind both methylated and unmethylated DNA. The short form of MBD3, however, displays a preference for methylated DNA. (E) Establishment of positive (ISWI) and negative (TFIIB) controls for DNA affinity precipitation.

DNA affinity precipitation of MBDs from oocyte extracts To optimize washing and elution conditions, the protein-DNA complexes formed during an overnight incubation of oocyte extracts and immobilized probes, were washed with increasing concentrations (100/200/ $400 \mathrm{mM}$ ) of $\mathrm{KCl}$ and eluted with Laemmli buffer. Once eluted with Laemmli buffer, the samples were spun down to separate the beads from the supernatant and the eluate was loaded on SDS-PAGE gel. Western blot analysis revealed strong preference for methylated DNA binding of both MBD3 and MeCP2 (Figure 2CD). The mammalian MBD3 is not able to bind methylated DNA due to an insertion in the MBD. Xenopus MBD3, however, is present in a short and a long form, the former of which is able to specifically bind methylated CpGs [5,47]. Whereas MeCP2 tolerates $200 \mathrm{mM}$ $\mathrm{KCl}$ in the washing buffer, most of MBD3 is eluted at such conditions (Figure 2C). MeCP2 and the short 
form of MBD3 display a strong preference for methylated DNA (Figure 2D), in contrast to $\mathrm{Mi}-2$ which can bind both methylated and unmethylated DNA. MBD3 and $\mathrm{Mi}-2$ form part of the same complex [5]; the difference in binding may be explained by a variable composition of the Mi-2/NuRD complex [48-50] and methylation-independent binding of DNA by the Mi-2/ NuRD subunit MTA1 [5]. Finally, a negative control for DNA methylation pull-downs was established. Any endogenous protein that does not bind directly to DNA might serve as a negative control in these assays. TFIIB is one of the general transcription factors involved in RNA Polymerase II pre-initiation complex formation [51]. Our assays identified it as a suitable negative control as it does not bind immobilized oligo templates independent of their methylation status (Figure $2 \mathrm{E}$ ). In the same experiment we also tested the binding of ISWI, another evolutionarily conserved ATP-dependent chromatin binding protein and established its uniform binding to methylated and unmethylated DNA [44,52] Altogether, these results establish Xenopus oocytes as an efficient system to probe for interactions of methylated DNA and proteins with methyl-CpG binding activity. Furthermore, we provide a number of controls that can be used in such assays to control for unspecific protein-DNA interactions.

\section{Methylated DNA affinity capture (MethylCap)}

A number of techniques to study DNA methylation on a genomic scale have been developed through the last decade. These include: Methylated DNA immunoprecipitation (MeDIP) [53-55], bisulfite sequencing [56,57] and methylated DNA affinity capture (MethylCap) $[38,41,58]$. These methods can be coupled to next generation sequencing technologies to identify the sites of genomic DNA methylation [40]. MethylCap is an affinity-based technique in which the immobilized methyl$\mathrm{CpG}$ binding domain of one of the MBDs is used to capture fragments of methylated DNA $[39,41,59,60]$ In order to obtain pure genomic DNA in sufficient quantities for the MethylCap assay, a genomic DNA isolation protocol has been optimized for Xenopus embryos (see materials and methods). This protocol yields $>1 \mu \mathrm{g}$ of genomic DNA from 100 late blastula/gastrula Xenopus tropicalis embryos (Figure 3A). In order to ensure proper resolution of the methylated DNA affinity capture, genomic DNA has to be sonicated to small fragments (200 - 300 bp). Xenopus genomic DNA samples were sonicated using a Bioruptor (Diagenode) device and sonicated genomic DNA was saved after five or fifteen minutes of sonication. The samples were then resolved on a $1 \%$ agarose gel (Figure 3B). Fifteen minutes of sonication (total volume $=200 \mu \mathrm{L}$, concentration $=0,1 \mu \mathrm{g} / \mu \mathrm{l})$ yields fragments of $200-300 \mathrm{bp}$. Sonicated genomic DNA was then bound to magnetic beads coated with the MeCP2 MBD domain (Figure 3C) and increasing $\mathrm{NaCl}$ concentrations were used to wash and elute the bound methylated DNA fragments. The recovery of methylated DNA was measured by quantitative PCR. The primers used to amplify affinity-precipitated fragments of genomic DNA correspond to DNA methylation-positive (tcea, tfcp2, gs17) and methylation-negative (Xbra, trim33, hes4) loci (Figure 3B). These genomic targets were validated by methylated DNA immunoprecipitation (MeDIP) (Figure 3E). Genomic targets $t c e a, t f c p 2$ and $g s 17$ are found positive for DNA methylation by both MeDIP and MethylCap. In line with benchmark studies $[40,41]$ the methylation status of the DNA fragments captured with this technique can be confirmed by bisulfite sequencing [38]. The majority of methylated fragments elute at high molar concentrations of $\mathrm{NaCl}(500 \mathrm{mM}, 700 \mathrm{mM})$ whereas the nonmethylated fragments are washed out at $200 \mathrm{mM}$, demonstrating the specific methylated-CpG affinity of the MBD resin (Figure 3B). Furthermore, to measure the amount of DNA captured in such an approach, fractions eluted at $500 \mathrm{mM}, 600 \mathrm{mM}$ and $700 \mathrm{mM} \mathrm{NaCl}$, were subjected to Picogreen measurement. All the examined fractions had a concentration of $>1 \mathrm{ng} / \mu \mathrm{l}$ (data not shown) making them highly suitable for next generation sequencing library preparation. Taken together, these results demonstrate an efficient approach to study DNA methylation in early vertebrate embryos.

\section{Discussion}

In this study we describe an efficient method for the pull-down of DNA methylation-specific proteins from Xenopus oocyte extracts. Furthermore, we demonstrate the functionality of this system by specifically pulling down two major Xenopus methyl-CpG binding proteins. In addition, we assay the ability of the methyl-CpG binding domain of MeCP2 to affinity-capture methylated genomic DNA and establish conditions that result in the elution of methylated fractions. Using methylated DNA affinity precipitation, MeCP2 and MBD3 were pulled down from Xenopus oocytes and positive as well as negative controls for this approach were established. The chromatin remodelers Mi-2 and ISWI can be used as loading controls and TFIIB as a negative control. Methylated DNA affinity precipitation is a valuable technique that can be coupled to western blotting or HDAC assays in order to assess the composition of bound fractions. Also, a great potential lies in combining methylated DNA pull-downs with mass spectrometry approaches to aid the identification of proteins with DNA methylation-specific binding. A number of recent studies demonstrated the importance of similar applications in identifying novel chromatin components in 


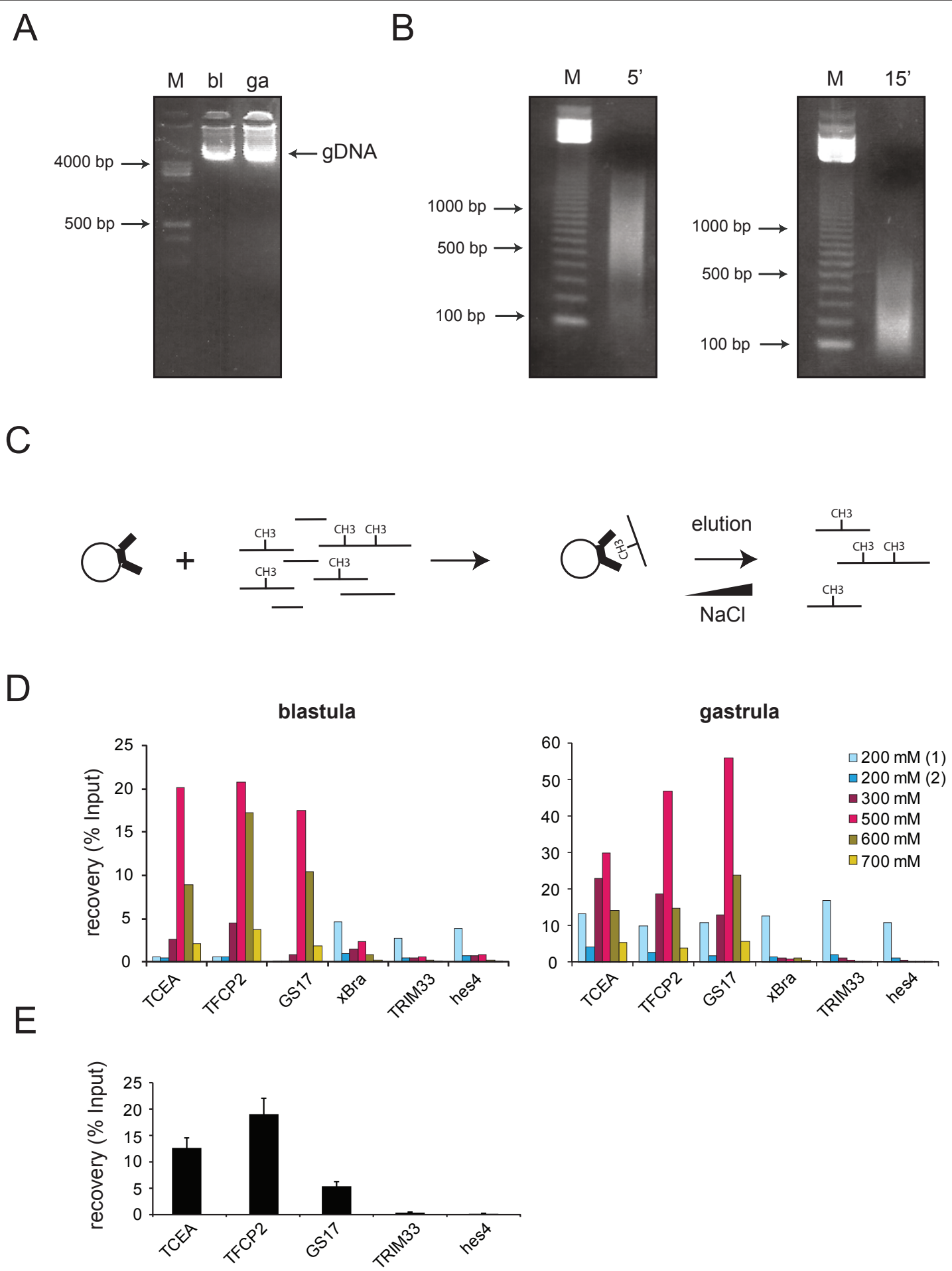

Figure 3 Genomic DNA isolation and sonication. (A) Xenopus tropicalis genomic DNA isolated from blastula (bl) and gastrula (ga) embryos. (B) Genomic DNA analyzed after 5 minutes or 15 minutes of sonication. Genomic DNA sonicated for 15 minutes yields fragments of 100 - 300 bp. (C) A schematic representation of methylated DNA affinity capture (MethylCap). Methylated DNA is bound by the immobilized methyl-CpG binding domain of $\mathrm{MeCP} 2$, washed and eluted with increasing $\mathrm{NaCl}$ concentrations. (D) PCR quantitation of methylated DNA recovery. DNA methylation targets (tcea, tfcp2 and gs 17) mostly elute at high $\mathrm{NaCl}$ concentrations ( $500 \mathrm{mM}, 600 \mathrm{mM}$ and $700 \mathrm{mM}$ ) whereas the nonmethylated targets (Xbra, trim33, hes4) are washed out with the first washing step (200 mM). (E) The methylation status of genomic targets tcea, tfcp2, gs 17, trim33 and hes 4 was validated by MeDIP (methylated DNA immunoprecipitation). The error bars represent standard deviation (SD) of two experiments. 
human cells [30]. The binding activity of methyl-CpG binding proteins in vertebrate oocytes/embryos has not yet been established. For example, in brain extracts, $\mathrm{MeCP} 2$ is known to be actively regulated by serine phosphorylation which diminishes its DNA binding affinity and enables the proper neural response $[17,19]$. It is possible that during early embryogenesis similar phosphorylation events, which result in altered binding affinity, take place. Also, MBD proteins are known to interact with a plethora of proteins and most of these interactions are dependent on the biological context [61]. Methylated DNA affinity precipitation coupled to mass spectrometry might help in identifying the nature of these interactions in the developing embryo. To capture methylated DNA, genomic DNA isolated from early Xenopus embryos was incubated with an MBD affinity resin and eluted with increasing salt concentrations. The fractions eluted at concentrations of $500-700 \mathrm{mM}$ $\mathrm{NaCl}$ contain fragments of highly methylated DNA $[38,40,41]$. On the other hand, the majority of nonmethylated fragments that were non-specifically bound to the resin already elute with $200 \mathrm{mM} \mathrm{NaCl}$. The relatively high concentration of DNA in the fractions renders this method highly suitable for coupling to next generation sequencing technologies.

\section{Conclusions}

Binding of MBDs to sites of genomic DNA methylation is a biologically important process that modulates the transcriptional output of the cell. It is therefore essential to have suitable assays to probe for this kind of interactions. Together, the two affinity-capture based assays discussed above, allow for unbiased profiling of methylated DNA-binding proteins and the genomic loci they may target, setting the stage for a new and exciting era of quantitative profiling in early vertebrate embryos.

\section{Statement on animal use}

Animal care and use was in accordance with national and European guidelines and standard operating procedures approved by the institutional animal care and use committee (Dierexperimentencommissie, DEC).

\section{Acknowledgements}

This work was funded by the grant of the Netherlands Organization of Scientific Research (NWO-ALW VIDI grant 864.03.002) to GJCV.

\section{Authors' contributions}

$\mathrm{OB}$ and GJCV designed the experiments, and drafted the manuscript. $O B$ Carried out the experiments. GJCV conceived the study and contributed to its design and to writing of the manuscript. Both authors read and approved the final manuscript.

\section{Competing interests}

The authors declare that they have no competing interests.
Received: 17 June 2011 Accepted: 18 August 2011

Published: 18 August 2011

\section{References}

1. Bird AP: CpG-rich islands and the function of DNA methylation. Nature 1986, 321(6067):209-213

2. Hendrich $B$, Tweedie S: The methyl-CpG binding domain and the evolving role of DNA methylation in animals. Trends Genet 2003, 19(5):269-277.

3. Jones PL, Veenstra GJ, Wade PA, Vermaak D, Kass SU, Landsberger N, Strouboulis J, Wolffe AP: Methylated DNA and MeCP2 recruit histone deacetylase to repress transcription. Nat Genet 1998, 19(2):187-191.

4. Zhang $Y, \mathrm{Ng} \mathrm{HH}$, Erdjument-Bromage H, Tempst P, Bird A, Reinberg D: Analysis of the NuRD subunits reveals a histone deacetylase core complex and a connection with DNA methylation. Genes Dev 1999, 13(15):1924-1935.

5. Wade PA, Gegonne A, Jones PL, Ballestar E, Aubry F, Wolffe AP: Mi-2 complex couples DNA methylation to chromatin remodelling and histone deacetylation. Nat Genet 1999, 23(1):62-66.

6. Nan X, Ng HH, Johnson CA, Laherty CD, Turner BM, Eisenman RN, Bird A: Transcriptional repression by the methyl-CpG-binding protein MeCP2 involves a histone deacetylase complex. Nature 1998, 393(6683):386-389.

7. Nan X, Meehan RR, Bird A: Dissection of the methyl-CpG binding domain from the chromosomal protein MeCP2. Nucleic Acids Res 1993, 21(21):4886-4892.

8. Hendrich B, Bird A: Identification and characterization of a family of mammalian methyl-CpG binding proteins. Mol Cell Biol 1998, 18(11):6538-6547.

9. Ruzov A, Dunican DS, Prokhortchouk A, Pennings S, Stancheva I, Prokhortchouk E, Meehan RR: Kaiso is a genome-wide repressor of transcription that is essential for amphibian development. Development 2004, 131(24):6185-6194.

10. Filion GJ, Zhenilo S, Salozhin S, Yamada D, Prokhortchouk E, Defossez PA: A family of human zinc finger proteins that bind methylated DNA and repress transcription. Mol Cell Biol 2006, 26(1):169-181.

11. Li E, Bestor $T H$, Jaenisch R: Targeted mutation of the DNA methyltransferase gene results in embryonic lethality. Cell 1992, 69(6):915-926.

12. Okano M, Bell DW, Haber DA, Li E: DNA methyltransferases Dnmt3a and Dnmt3b are essential for de novo methylation and mammalian development. Cell 1999, 99(3):247-257.

13. Stancheva I, Meehan RR: Transient depletion of xDnmt1 leads to premature gene activation in Xenopus embryos. Genes Dev 2000, 14(3):313-327.

14. Iwano H, Nakamura M, Tajima S: Xenopus MBD3 plays a crucial role in an early stage of development. Dev Biol 2004, 268(2):416-428.

15. Amir RE, Van den Veyver IB, Wan M, Tran CQ, Francke U, Zoghbi HY: Rett syndrome is caused by mutations in X-linked MECP2, encoding methylCpG-binding protein 2. Nat Genet 1999, 23(2):185-188.

16. Shahbazian MD, Zoghbi HY: Molecular genetics of Rett syndrome and clinical spectrum of MECP2 mutations. Curr Opin Neurol 2001, 14(2):171-176.

17. Martinowich $K$, Hattori D, Wu H, Fouse $S$, He F, Hu Y, Fan G, Sun YE: DNA methylation-related chromatin remodeling in activity-dependent BDNF gene regulation. Science 2003, 302(5646):890-893.

18. Chen WG, Chang Q, Lin Y, Meissner A, West AE, Griffith EC, Jaenisch R, Greenberg ME: Derepression of BDNF transcription involves calciumdependent phosphorylation of MeCP2. Science 2003, 302(5646):885-889.

19. Tao J, Hu K, Chang Q, Wu H, Sherman NE, Martinowich K, Klose RJ, Schanen $C$, Jaenisch $R$, Wang W, et al: Phosphorylation of MeCP2 at Serine 80 regulates its chromatin association and neurological function. Proc Natl Acad Sci USA 2009, 106(12):4882-4887.

20. Zhou Z, Hong EJ, Cohen S, Zhao WN, Ho HY, Schmidt L, Chen WG, Lin Y, Savner E, Griffith EC, et al: Brain-specific phosphorylation of MeCP2 regulates activity-dependent Bdnf transcription, dendritic growth, and spine maturation. Neuron 2006, 52(2):255-269

21. Smith $A D$, Sumazin $P$, Das D, Zhang MQ: Mining ChIP-chip data for transcription factor and cofactor binding sites. Bioinformatics 2005, 21(Suppl 1):i403-412. 
22. Valouev A, Johnson DS, Sundquist A, Medina C, Anton E, Batzoglou S, Myers RM, Sidow A: Genome-wide analysis of transcription factor binding sites based on ChIP-Seq data. Nat Methods 2008, 5(9):829-834.

23. Guille MJ, Kneale GG: Methods for the analysis of DNA-protein interactions. Mol Biotechnol 1997, 8(1):35-52.

24. Jiang D, Jarrett HW, Haskins WE: Methods for proteomic analysis of transcription factors. J Chromatogr A 2009, 1216(41):6881-6889.

25. Kadonaga JT, Tjian R: Affinity purification of sequence-specific DNA binding proteins. Proc Natl Acad Sci USA 1986, 83(16):5889-5893.

26. Gadgil H, Oak SA, Jarrett HW: Affinity purification of DNA-binding proteins. J Biochem Biophys Methods 2001, 49(1-3):607-624.

27. Lombard-Platet $G$, Jalinot P: Purification by DNA affinity precipitation of the cellular factors HEB1-p67 and HEB1-p94 which bind specifically to the human T-cell leukemia virus type-I 21 bp enhancer. Nucleic Acids Res 1993, 21(17):3935-3942.

28. Vermeulen M, Stunnenberg HG: An in vitro assay to study the recruitment and substrate specificity of chromatin modifying enzymes. Biol Proced Online 2004, 6:157-162

29. Vermeulen M, Mulder KW, Denissov S, Pijnappel WW, van Schaik FM, Varier RA, Baltissen MP, Stunnenberg HG, Mann M, Timmers HT: Selective anchoring of TFIID to nucleosomes by trimethylation of histone $\mathrm{H} 3$ lysine 4. Cell 2007, 131(1):58-69.

30. Vermeulen M, Eberl HC, Matarese F, Marks H, Denissov S, Butter F, Lee KK, Olsen JV, Hyman AA, Stunnenberg HG, et al: Quantitative interaction proteomics and genome-wide profiling of epigenetic histone marks and their readers. Cell 2010, 142(6):967-980.

31. Bartke $T$, Vermeulen $M$, Xhemalce $B$, Robson SC, Mann M, Kouzarides T: Nucleosome-interacting proteins regulated by DNA and histone methylation. Cell 2010, 143(3):470-484.

32. Ong SE, Foster LJ, Mann M: Mass spectrometric-based approaches in quantitative proteomics. Methods 2003, 29(2):124-130.

33. Stancheva I, Collins AL, Van den Veyver IB, Zoghbi H, Meehan RR: A mutant form of MeCP2 protein associated with human Rett syndrome cannot be displaced from methylated DNA by notch in Xenopus embryos. $\mathrm{Mo}$ Cell 2003, 12(2):425-435.

34. Dunican DS, Ruzov A, Hackett JA, Meehan RR: xDnmt1 regulates transcriptional silencing in pre-MBT Xenopus embryos independently of its catalytic function. Development 2008, 135(7):1295-1302.

35. Ruzov A, Shorning B, Mortusewicz O, Dunican DS, Leonhardt H, Meehan RR: MBD4 and MLH1 are required for apoptotic induction in XDNMT1depleted embryos. Development 2009, 136(13):2277-2286.

36. Akkers RC, van Heeringen SJ, Jacobi UG, Janssen-Megens EM, Francoijs KJ, Stunnenberg HG, Veenstra GJ: A hierarchy of H3K4me3 and H3K27me3 acquisition in spatial gene regulation in Xenopus embryos. Dev Cell 2009, 17(3):425-434.

37. van Heeringen SJ, Akhtar W, Jacobi UG, Akkers RC, Suzuki Y, Veenstra GJ: Nucleotide composition-linked divergence of vertebrate core promoter architecture. Genome Res 2011, 21(3):410-421.

38. Bogdanovic O, Long SW, van Heeringen SJ, Brinkman AB, GomezSkarmeta JL, Stunnenberg HG, Jones PL, Veenstra GJ: Temporal uncoupling of the DNA methylome and transcriptional repression during embryogenesis. Genome Res 2011.

39. Kangaspeska S, Stride B, Metivier R, Polycarpou-Schwarz M, Ibberson D, Carmouche RP, Benes V, Gannon F, Reid G: Transient cyclical methylation of promoter DNA. Nature 2008, 452(7183):112-115.

40. Bock C, Tomazou EM, Brinkman AB, Muller F, Simmer F, Gu H, Jager N, Gnirke A, Stunnenberg HG, Meissner A: Quantitative comparison of genome-wide DNA methylation mapping technologies. Nat Biotechnol 2010, 28(10):1106-1114.

41. Brinkman AB, Simmer F, Ma K, Kaan A, Zhu J, Stunnenberg HG: Wholegenome DNA methylation profiling using MethylCap-seq. Methods 2010 52(3):232-236

42. Klose RJ, Sarraf SA, Schmiedeberg L, McDermott SM, Stancheva I, Bird AP: DNA binding selectivity of MeCP2 due to a requirement for $A / T$ sequences adjacent to methyl-CpG. Mol Cell 2005, 19(5):667-678.

43. Guschin D, Wade PA, Kikyo N, Wolffe AP: ATP-Dependent histone octamer mobilization and histone deacetylation mediated by the $\mathrm{Mi}-2$ chromatin remodeling complex. Biochemistry 2000, 39(18):5238-5245.

44. Kikyo N, Wade PA, Guschin D, Ge H, Wolffe AP: Active remodeling of somatic nuclei in egg cytoplasm by the nucleosomal ATPase ISWI. Science 2000, 289(5488):2360-2362.
45. Veenstra GJ, Destree OH, Wolffe AP: Translation of maternal TATA-binding protein mRNA potentiates basal but not activated transcription in Xenopus embryos at the midblastula transition. Mol Cell Biol 1999, 19(12):7972-7982.

46. Jallow Z, Jacobi UG, Weeks DL, Dawid IB, Veenstra GJ: Specialized and redundant roles of TBP and a vertebrate-specific TBP paralog in embryonic gene regulation in Xenopus. Proc Natl Acad Sci USA 2004 101(37):13525-13530

47. Saito M, Ishikawa F: The mCpG-binding domain of human MBD3 does not bind to $\mathrm{mCpG}$ but interacts with NuRD/Mi2 components HDAC1 and MTA2. J Biol Chem 2002, 277(38):35434-35439.

48. Le Guezennec X, Vermeulen M, Brinkman AB, Hoeijmakers WA, Cohen A Lasonder E, Stunnenberg HG: MBD2/NuRD and MBD3/NuRD, two distinct complexes with different biochemical and functional properties. $\mathrm{Mol}$ Cell Biol 2006, 26(3):843-851.

49. Passannante M, Marti CO, Pfefferli C, Moroni PS, Kaeser-Pebernard S, Puoti A, Hunziker P, Wicky C, Muller F: Different Mi-2 complexes for various developmental functions in Caenorhabditis elegans. PLoS One 2010, 5(10):e13681

50. Yao YL, Yang WM: The metastasis-associated proteins 1 and 2 form distinct protein complexes with histone deacetylase activity. J Biol Chem 2003, 278(43):42560-42568

51. Roeder RG: The role of general initiation factors in transcription by RNA polymerase II. Trends Biochem Sci 1996, 21(9):327-335.

52. Guschin D, Geiman TM, Kikyo N, Tremethick DJ, Wolffe AP, Wade PA: Multiple ISWI ATPase complexes from xenopus laevis. Functional conservation of an ACF/CHRAC homolog. J Biol Chem 2000, 275(45):35248-35255

53. Weber M, Davies JJ, Wittig D, Oakeley EJ, Haase M, Lam WL, Schubeler D: Chromosome-wide and promoter-specific analyses identify sites of differential DNA methylation in normal and transformed human cells. Nat Genet 2005, 37(8):853-862.

54. Mohn F, Weber M, Schubeler D, Roloff TC: Methylated DNA immunoprecipitation (MeDIP). Methods Mol Biol 2009, 507:55-64.

55. Jia J, Pekowska A, Jaeger S, Benoukraf T, Ferrier P, Spicuglia S: Assessing the efficiency and significance of Methylated DNA Immunoprecipitation (MeDIP) assays in using in vitro methylated genomic DNA. BMC Res Notes 2010, 3:240.

56. Meissner A, Mikkelsen TS, Gu H, Wernig M, Hanna J, Sivachenko A, Zhang X Bernstein BE, Nusbaum C, Jaffe DB, et al: Genome-scale DNA methylation maps of pluripotent and differentiated cells. Nature 2008 , 454(7205):766-770

57. Lister R, Pelizzola M, Dowen RH, Hawkins RD, Hon G, Tonti-Filippini J, Nery JR, Lee L, Ye Z, Ngo QM, et al: Human DNA methylomes at base resolution show widespread epigenomic differences. Nature 2009, 462(7271):315-322

58. Martens $J H$, Brinkman AB, Simmer F, Francoijs KJ, Nebbioso A, Ferrara F, Altucci L, Stunnenberg HG: PML-RARalpha/RXR Alters the Epigenetic Landscape in Acute Promyelocytic Leukemia. Cancer Cell 2010, 17(2):173-185.

59. Cross SH, Charlton JA, Nan X, Bird AP: Purification of CpG islands using a methylated DNA binding column. Nat Genet 1994, 6(3):236-244.

60. Serre D, Lee BH, Ting AH: MBD-isolated Genome Sequencing provides a high-throughput and comprehensive survey of DNA methylation in the human genome. Nucleic Acids Res 2010, 38(2):391-399.

61. Bogdanovic O, Veenstra GJ: DNA methylation and methyl-CpG binding proteins: developmental requirements and function. Chromosoma 2009, 118(5):549-565.

doi:10.1186/1756-0500-4-300

Cite this article as: Bogdanović and Veenstra: Affinity-based enrichment strategies to assay methyl-CpG binding activity and DNA methylation in early Xenopus embryos. BMC Research Notes 2011 4:300. 